\title{
The Impact of University Student’ s Green Awareness Purchasing on Green Marketing in Egypt
}

EI Sakka $\mathrm{S}^{*}$

Department of management, School of Business, Future University in Egypt, 5th Settlement, New Cairo, Egypt

"Corresponding author: El Sakka S, Department of management, School of Business, Future University in Egypt, 5Th Settlement, New Cairo, Egypt, Tel: +202 26186100; E-mail: sherinesakka@fue.edu.eg

Received date: May 20, 2016; Accepted date: Jun 17, 2016; Published date: Jun 27, 2016

Copyright: ( 2016 El Sakka S. This is an open-access article distributed under the terms of the Creative Commons Attribution License, which permits unrestricted use, distribution, and reproduction in any medium, provided the original author and source are credited.

\begin{abstract}
Egypt as one of the developing countries which confront a lot environmental challenges, environmental issues and green products culture is not a priority, spreading the ideas of going green and expanding the culture of green product purchase (GPP) is very important step which it need awareness campaign for green marketing to clarify for new generation the benefit of purchasing green products.

Our paper will investigate how much young Egyptians university students are aware about green product (GP), if the awareness impacts their green product purchase (GPP) and how it might influence their consumer behaviour; we will discover what kind of factors could affect Egyptian university students buying behaviour of green products and green services.
\end{abstract}

Keywords: Green product purchasing (GPP); Awareness purchase (AP); Green product (GP)

\section{Introduction}

Climate changes, global warming, air and water pollution, Eco friendly products, and green marketing are some environment issues popped up internationally and nationally nowadays.

These environmental issues have impact on consumer health, which made producers to think green and to promote for green products and services.

Egypt like other developing country, confront a lot of environmental problems, from water pollution, air pollution, agriculture land problem, and unsuccessful waste management problem, due to economic problems there is community lack awareness about the environment its problem and its products actually there is no priority of the environmental issues in front of the economy.

Our study will try to discover how much young Egyptians are aware about green product and its consumption benefits as a way to highlights the importance of green products consumption.

This paper will be structured as follows, a brief literature review on green marketing and student green product awareness will be discussed, research methodology, statistical analysis result, finally conclusions and recommendations.

\section{Literature Review}

\section{Green marketing}

According to American marketing association it defines green marketing "as marketing of products that are believed to be environment friendly which organize into various activities such as product adjustment, modification of production processes, packaging, labeling, advertising strategies as well as increases awareness on compliance marketing among industries" [1]

Ruth Dettie [2] define green marketing as "the application of marketing tools to facilitate exchanges that satisfy organizational and individual goals in such a way that the preservation, protection and conservation of the natural environment are upheld.

Arita khare [3] state that green marketing relates to a holistic management approach for identifying, anticipating and satisfying the needs of consumers and society in a profitable and sustainable way [3]

According to Leslilelu [4] green marketing is defined as "a strategic effort made by firms to provide customers with the environment friendly merchandise."

\section{Green marketing tools}

Eco label, eco brand and environmental advertisement are green marketing tools which can increase green products features and help consumers to buy green products.

Eco Label: it's a tool which allows consumers to easily distinguish environmentally green product between the ordinary products.

Eco brand: applying it aspects could help consumers to recognize green products between other products which could harm the environment.

Environmental advertisement: it's a way to redirect the attention of customer to The benefit of purchasing green product [4].

\section{Benefit of green marketing}

Green marketing can help building a brand value

Green marketing can eliminate the bad effect of production and better the image of the product. 
In green marketing the cost of raw materials are low and the price of green product is low on the long term [5].

\section{Green consumer}

The consumer who support business that operate in the environmental friendly ways according to Jen Mei [6].

Green consumption behavior controlled by several factors such as changing consumption value and awareness of green product benefits, demographic factors like age, education and income the more the consumer is exposed the more his consumer behavior change; also factors like price and quality of green products has an impact.

According to Schuhwerkan individuals who engage in environmental activities are devoted to purchase green goods.

Green consumers not only consuming green products but also deals with Company's has engagements green practices and activities such as recycling and energy efficiency.

According to Vermillion Consumers are not likely to purchase a product only for it's environmentally attributes.

Green consumer is define as "products that are likely to endanger the health of the consumer or others, cause significant damage to the environment during manufacture, use of disposal, consume a disproportionate amount of energy, cause of harming waste, use materials derived from threatened species or environments" [7].

According to previous studies children and teens influenced by their family's green product and service consumption, consumers are influenced as well by the product price they post pone their choices to buy green products to a time when they can afford it [8].

\section{Green consumer categories}

Roper Organization, categories consumers to five segments

True blue green: when consumer believe that their green consumption have an impact on the environment, they have a will to invest on green products and engage in ecological activities.

Green back green: when consumer invests in more expensive green products but is not willing to engage in environmental activities.

Sprouts: green consumer who support environmental regulations, but they are less to spend money on green products.

Grousers: believe that it's not his responsibility to solve environmental issues; they use regular products and avoid consumption of green products.

Basic browns: believe that environmental problems are very complicated no efforts on personal, commercial or political levels can solve any ecological problem [9].

Hunger stated customers could have an attitude towards green purchases but this doesn't guarantee that they will purchase green products

According to Gatersleben 2012 he clarify that people who consume green products are the young generation [10].

\section{Green product}

A product which has ecological attribute the use of green products its aim to prevent pollution and reserve resources, the problem of green product use is its cost and that no many consumers could afford it specially in developing countries when the income is low [11].

\section{Consumer purchasing behavior}

Is the decision process and acts of people involved in buying and using product [12].

\section{The history of going green idea and its implementation}

The force of going green idea started in western marketing at the millennium and then expanded in Asia and Africa, from 1990 consumers worldwide started to become socially and environmentally aware of the importance of the environment issues.

The concept of ecofriendly or going green approach was pushed by the developed countries to initiate international green marketing in order to expand their market and to take advantage of the positive image of their green brand established in their domestic markets.

Lately there is an increase towards green behaviour due to the population increase and resources drain more can Egypt handle it as a developing country, and due to its economic situation it rely on some industries which could harm its environment like ceramic and cement, so we have to discover what is Egyptian consumers awareness situation considering green products.

Consumers environmental knowledge can be improved through education, some of previous studies stated that many consumers fail to understand the connection between their buying decision and environmental consequences.

After the United Nations conference in 1972 the 21st century become a green consumption Era all over the world, the word green gained attention according to previous studies they showed that knowledgeable consumers of ecological problems purchase environmentally friendly products, consumers with high knowledge are more willing to pay higher prices to support green products [13].

The four criteria for achieving the principles of green consumptions are known as the $4 \mathrm{Rs}$, (reduction, reuse, recycling and recognition) [14].

\section{Socioeconomic environment of Egypt}

According to the World Bank classifications, Egypt is a lower middle income country, the 2010 millennium development goal report highlights that poverty is one of the most critical areas of deficit in Egypt; Egypt has a lot of problematic issues concerning the environment, climate change, water sacristy, coastal problem and air pollution, Egypt has a mismanagement of natural resources which make the awareness process for the population about consuming green product a kind of luxury [14,15].

\section{Environmental Awareness}

The more people are knowledgeable about green products and its practices the more they will act positively (Roberts 1996), environmental awareness considered as knowledge and general concepts relating to the ecosystems. 


\section{Government initiative in Egypt}

The government's role is a predictor to green purchasing behavior claiming Punitha \& Rahman (2011) according to them that government should play a role in building green purchasing, Egypt pursue long term developments goals taking into consideration at its policies social and environmental dimension.

\section{Research Methodology}

\section{Research objectives}

To investigate the awareness level of Egyptian university students about green marketing

To measure the green value for Egyptian university students

To understand what factors could persuade Egyptian university students to buy green products or use green services

To discuss if students environmental responsibility could impact their consumption behaviour

\section{Research questions}

Is there awareness of green marketing between university students?

Is there a green value between Egyptian university students?

What are the factors which could influence university students to buy green products?

Are students environmental responsibility could impact their consumption behaviour?

\section{Population and sampling}

The populations researched were a random sample of future, British and the German universities students in Egypt aged between 18 to 24 years, a quantitative study, and self-administrated questionnaires had been conducted .

The main reasons for choosing this sample was as follows.

To explore the awareness of green product for young generation.

The sample chosen expected to represent consumer's behaviour for green product in the future.

\section{Hypothesis}

H0: There is no significant relation between Egyptian university student's awareness and green consumption purchase

H1: There is a significant relation between Egyptian university student's awareness and green consumption purchase

\section{Findings and discussion}

Respondent's surveys were not aware of green products, consumption benefits and practices

\section{Data collection and analysis}

\begin{tabular}{|l|l|l|}
\hline Green marketing awareness & Mean & $\begin{array}{l}\text { Std } \\
\text { Deviation }\end{array}$ \\
\hline $\begin{array}{l}\text { Time spent discussing with your friends green products } \\
\text { importance }\end{array}$ & 2.06 & 1.441 \\
\hline $\begin{array}{l}\text { Time spent with your friends discussing environmental } \\
\text { problems issue }\end{array}$ & 2.38 & 1.575 \\
\hline $\begin{array}{l}\text { Time spent sharing information regarding green products } \\
\text { with your friends }\end{array}$ & 2.36 & 1.474 \\
\hline $\begin{array}{l}\text { Sharing information about the benefit of green product } \\
\text { consumption }\end{array}$ & 4.09 & 889 \\
\hline $\begin{array}{l}\text { The importance of raising green products awareness } \\
\text { among university students }\end{array}$ & 4.48 & 703 \\
\hline
\end{tabular}

Table 1: student's perception about green products awareness.

As revealed from the previous table (Table 1) the awareness of the students about green products it's not high, the data standard deviation measured are not concentrated around the mean. Awareness about green product should be raised between universities students and more protection works its need it (Table 2).

\begin{tabular}{|l|l|l|}
\hline Cronbach's alpha & $\begin{array}{l}\text { Cronbash alpha based on } \\
\text { standardized items }\end{array}$ & No of items \\
\hline 310 & 277 & 5 \\
\hline
\end{tabular}

Table 2: Green products students' awareness scale reliability analysis.

The alpha coefficient for the 5 items have relatively low internal consistency as it is, 277 (Table 3).

\begin{tabular}{|l|l|l|}
\hline Green value between students & Mean & Std deviation \\
\hline $\begin{array}{l}\text { It's essential to promote green living } \\
\text { concept in Egypt }\end{array}$ & 4.09 & 889 \\
\hline $\begin{array}{l}\text { Green products consumption is a waste } \\
\text { of money and resources }\end{array}$ & 2.67 & 1.4 \\
\hline $\begin{array}{l}\text { Green products consumption issues are } \\
\text { not of my interest }\end{array}$ & 2.45 & 1.00 \\
\hline $\begin{array}{l}\text { Consumption of green products is } \\
\text { meaningless }\end{array}$ & 2.47 & 1.02 \\
\hline $\begin{array}{l}\text { Worry about worsening of the quality } \\
\text { products in Egypt }\end{array}$ & 4.00 & 865 \\
\hline $\begin{array}{l}\text { Using green products as a step to } \\
\text { change consumer behavior one of my } \\
\text { major concern }\end{array}$ & 3.6 & 1.00 \\
\hline $\begin{array}{l}\text { Involved in environmental protection } \\
\text { issues in Egypt }\end{array}$ & 3.21 & 710 \\
\hline $\begin{array}{l}\text { Ege green products improvement in } \\
\text { Egypt should be a priority }\end{array}$ & 3.43 & 656 \\
\hline $\begin{array}{l}\text { Green products market expansion in } \\
\text { Egypt need to be dealt }\end{array}$ & 4.02 & 1.28 \\
\hline $\begin{array}{l}\text { Egypt is worsening } \\
\text { then the green products problem in }\end{array}$ & 4.21 & 14 \\
\hline
\end{tabular}


Page 4 of 5

\begin{tabular}{|l|l|l|}
\hline $\begin{array}{l}\text { Usage Non green products threat our } \\
\text { health }\end{array}$ & 4.30 & 577 \\
\hline $\begin{array}{l}\text { Non usage of green products problem } \\
\text { threat Egypt reputation }\end{array}$ & 4.11 & 853 \\
\hline
\end{tabular}

Table 3: Green value between Egyptian university students.

Green value is not that high between Egyptian university students, standard deviation show values that data set is not around the mean, the more the standard deviation is smaller the more the data are concentrated around the mean and this is shows in the students opinion that the green living should be promoted in Egypt, it shoes std, 886 while the mean is 4.09 , and how they are worry about the worsening the quality of Egypt environment std of 0.865 while the mean is 4.00, they think that problem in Egypt should be dealt std of 710 while the mean is 4.02 , they think that environmental problem threat their health std of 577 with a mean of 4.30 , they are concerned also about Egypt reputation std of 853 with a mean of 4.11(Table 4).

\begin{tabular}{|l|l|l|}
\hline Cronbach's alpha & $\begin{array}{l}\text { Cronbash alpha based on } \\
\text { standardized items }\end{array}$ & No of items \\
\hline 499 & 542 & 12 \\
\hline
\end{tabular}

Table 4: Green value scale reliability analysis between Egyptian university students.

The alpha coefficient for the 12 items has relatively low internal consistency as it is, 542 (Table 5 and 6).

\begin{tabular}{|l|l|l|}
\hline $\begin{array}{l}\text { Factors could influence students to buy green } \\
\text { products }\end{array}$ & Mean & $\begin{array}{l}\text { Std } \\
\text { deviation }\end{array}$ \\
\hline $\begin{array}{l}\text { Green product is } \\
\text { Expensive in Egypt }\end{array}$ & 3.46 & 1.40 \\
\hline $\begin{array}{l}\text { Non availability of green product everywhere create } \\
\text { a consumption barrier }\end{array}$ & 3.66 & 1.29 \\
\hline $\begin{array}{l}\text { Its unwise to spend a big amount for green product } \\
\text { consumption }\end{array}$ & 2.89 & 1.17 \\
\hline $\begin{array}{l}\text { Green products and green services need high } \\
\text { income }\end{array}$ & 3.38 & 1.03 \\
\hline Brand image could persuade to buy green products & 3.94 & 824 \\
\hline $\begin{array}{l}\text { Awareness of green product price could persuade } \\
\text { to change consumption behavior }\end{array}$ & 3.82 & 687 \\
\hline
\end{tabular}

Table 5: Factors could influence university students to buy green products.

\begin{tabular}{|l|l|l|}
\hline Cornbrash's alpha & $\begin{array}{l}\text { Cronbash alpha based on } \\
\text { standardized items }\end{array}$ & No of items \\
\hline 120 & 202 & 6 \\
\hline
\end{tabular}

Table 6: Factors scale reliability analysis could influence university students to buy green products.

The alpha coefficient for the 6 items have relatively low internal consistency as it is, 202 (Table 7).

\begin{tabular}{|l|l|l|}
\hline Environmental students responsibilities & Mean & $\begin{array}{l}\text { Std } \\
\text { deviation }\end{array}$ \\
\hline $\begin{array}{l}\text { You should be responsible for protecting our } \\
\text { environment }\end{array}$ & 4.01 & 759 \\
\hline $\begin{array}{l}\text { Environmental protection starts with buying } \\
\text { green products }\end{array}$ & 3.21 & 1.14 \\
\hline $\begin{array}{l}\text { How much responsibility do you think you have } \\
\text { in protecting the environment in Egypt }\end{array}$ & 3.91 & 1,102 \\
\hline $\begin{array}{l}\text { Do you have the will to buy green products as a } \\
\text { part of your responsibility to protect the } \\
\text { environment in Egypt }\end{array}$ & 3.67 & 766 \\
\hline $\begin{array}{l}\text { Environmental protection is the responsibility of } \\
\text { Egypt government not you }\end{array}$ & 3.44 & 1.402 \\
\hline $\begin{array}{l}\text { Environmental protection is the responsibility of } \\
\text { environmental organizations }\end{array}$ & 3.53 & 1.123 \\
\hline $\begin{array}{l}\text { If you carry out some pro environmental } \\
\text { behaviors by buying green products in your } \\
\text { everyday life you would contribute a lot in } \\
\text { changing consumption behavior }\end{array}$ & 4.01 & 659 \\
\hline $\begin{array}{l}\text { Your participation in buying green products } \\
\text { would encourage your family and friends to } \\
\text { participate in changing their consumption } \\
\text { behavior }\end{array}$ & 3.86 & 1.314 \\
\hline $\begin{array}{l}\text { Environmental quality in Egypt will stay the same } \\
\text { even if you engage in some pro-environmental } \\
\text { behaviors }\end{array}$ & 2.76 & 2.97 \\
\hline $\begin{array}{l}\text { Even if you buy green product recycle and reuse } \\
\text { stuff, the consumption behavior will remains as it } \\
\text { is }\end{array}$ & 2.97 \\
\hline
\end{tabular}

Table 7: Student's environmental responsibility could impact their consumption behaviour.

Responsibility for protecting community environment shows a std of 759 and mean of 4.01 , willing to take responsibility to protect the environment in Egypt shows Std of 766 and mean of 3.67, carrying pro-environment behavior with std, 569 and mean of 4.01, encouraging family and friends to protect the environment std of ,817 with a mean of 3.86 (Table 8 ).

\begin{tabular}{|l|l|l|}
\hline Cronbach's alpha & $\begin{array}{l}\text { Cronbash alpha based on } \\
\text { standardized items }\end{array}$ & No of items \\
\hline 543 & 570 & 10 \\
\hline
\end{tabular}

Table 8: Student's environmental responsibility scale reliability analysis could impact their consumption behaviour.

The alpha coefficient for the 10 items has relatively low internal consistency as it is $\mathbf{5 7 0}$

\section{Conclusion}

There is no high awareness for green marketing between private Egyptian universities students; also there is no high green value between them as well, they don't differentiate between green products and non-green products, they don't know the importance of buying green products and how they will participate in saving and protecting the Egyptian environment by going green, the factors like green 
product price, availability of green product in the markets and brand image could influence university students to buy green products, student's environmental responsibility could impact their consumption behaviour if they aware of the benefit of the consumption of green products and if the green product has a reasonable price and available everywhere.

The relationship between awareness and green products consumption is positive, which mean the more an individual's awareness the more his consumption behaviour towards green products

\section{Recommendation}

Awareness campaigns about green products importance and its benefits, is recommended between Egyptian universities students

Environmental issues should be included in education program to help students to know the relation between going green and how consumer behaviour changes could solve environment problems.

Students involvement in finding solution for community environmental problems

Government should highlight the importance of green product awareness campaign in public universities as well as in private as a priority in its agenda

Reinforcement of environmental laws in Egypt will help to highlight the importance of the environment as well as using green products.

\section{Contribution}

This study contributes to the theory by adding current literature on green buying behaviour awareness among young consumer in some of private universities in Egypt; it contributes to the practice by shading the light on the importance of the awareness of green products for young generation in Egypt as one of the developing countries.

\section{Limitations of the research}

This study was limited to students in some private universities in Egypt and did not cover all the universities in Egypt, in future studies it would be ideal to major the awareness of the students in all Egypt universities on both sectors public and private.
Secondly, this study concentrated on green product awareness in general, further studies could focus on specific process of green product awareness which can generate a more reliable response.

\section{References:}

1. Global journal 2015 p. 2.

2. Ruth Dettie, kevein Burchell, Debra Riely (2012) Normalizing green behaviors a new approach to sustainability marketing. J of marketing management 28: 423.

3. Arita khare, Sourjo mukerjee, Tanuj goyal (2013) Social influence and green marketing an exploratory study on indian consumers. J customer behavior 12: 362 .

4. Leslilelu, Dora Bock, Mathew joseph (2013) Green marketing: what the millennials buy, Journal of business strategy 34: 3-10.

5. Wong Fuiyeng, Rashad Yaz dnifard (2015) Green marketing a study of consumers buying behavior in relation to green products. Global journal 4-5.

6. Ooi jen Mei, Kwek choon Ling, Tan Hoi (2012) Piew The antecedents of green purchase intention among Malysian consumers 8: 249.

7. Elham rahbar, Nabsiah abul wahid (2007) Investigation of green marketing tools effect on consumers purchase behavior 12: 73-83.

8. Jesicca Ascheman-witzel, Emilie marie niebahr (2014) Elaborating products: young Danish consumer and in store food choice. International journal of consumer 38: 552 .

9. Kaman Lee (2008) Opportunities for green marketing: young consumers. Journal of consumer marketing 26: 573-586.

10. Muntaha Anwar, Marike Venter (2014) Attitudesand purchase Behavior of green products among generation Y consumers in south Africa. Mediteranian Journal of social sciences 5 .

11. Violeta, Sima (2014) Green behavior of the Romanian consumers, Economic insights trends and challenges 111: 66-77.

12. Hisham el din bin, Ismail, Mohamed fateh ali khan (2008) Consumer perception on the consumerism issue and its influence on their purchasing behavior, A view from Malaysian food industry pp 11: 43 .

13. Lynsey Scott, Debbie Vigar-Ellis (2014) Consumer understanding perceptions and behavior with regard to environmentally friendly packaging in a developing nation, International journal of consumer studies 38: 2-4.

14. Cheng-juri Tseng, Shuo chang Tsaj (2011) Effect of consumer environmental attitude of green consumption decision making. pack J statist 27: 1-4.

15. Iman F Abou-El naga (2015) Demographic, socioeconomic and environmental changes affecting circulation of neglected tropical diseases in Egypt. Asian pac j Trop med 8: 881-888. 